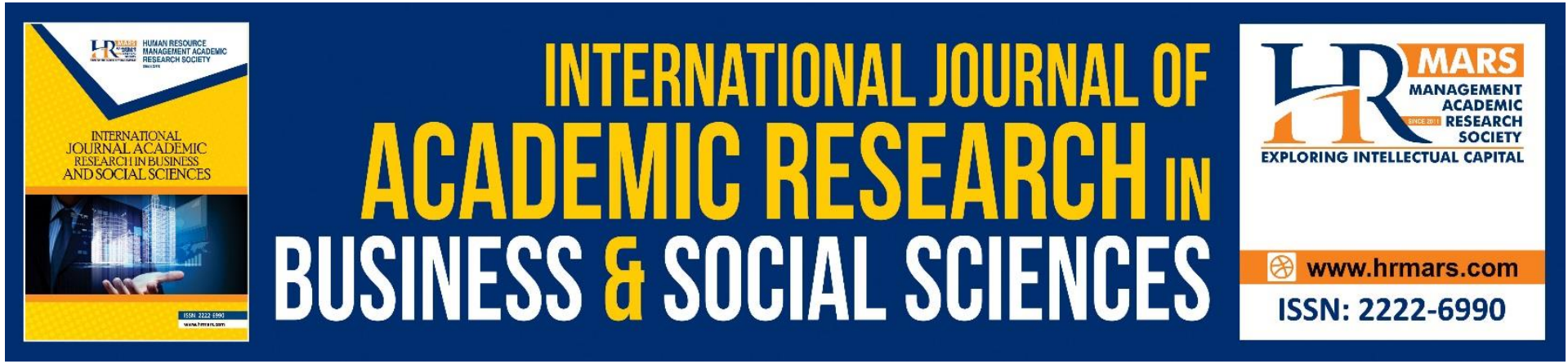

\title{
The Mutual Respect Method for Motivating Leaders and Followers
}

Noor Hidayah Samsudin, Fadzila Azni Ahmad

To Link this Article: http://dx.doi.org/10.6007/IJARBSS/v11-i7/10413

DOI:10.6007/IJARBSS/v11-i7/10413

Received: 12 May 2021, Revised: 16 June 2021, Accepted: 25 June 2021

Published Online: 02 July 2021

In-Text Citation: (Samsudin \& Ahmad, 2021)

To Cite this Article: Samsudin, N. H., \& Ahmad, F. A. (2021). The Mutual Respect Method for Motivating Leaders and Followers. International Journal of Academic Research in Business and Social Sciences, 11(6), 35-46.

\section{Copyright: @ 2021 The Author(s)}

Published by Human Resource Management Academic Research Society (www.hrmars.com)

This article is published under the Creative Commons Attribution (CC BY 4.0) license. Anyone may reproduce, distribute, translate and create derivative works of this article (for both commercial and non-commercial purposes), subject to full attribution to the original publication and authors. The full terms of this license may be seen at: http://creativecommons.org/licences/by/4.0/legalcode

Vol. 11, No. 7, 2021, Pg. 35 - 46

http://hrmars.com/index.php/pages/detail/IJARBSS

Full Terms \& Conditions of access and use can be found at http://hrmars.com/index.php/pages/detail/publication-ethics 


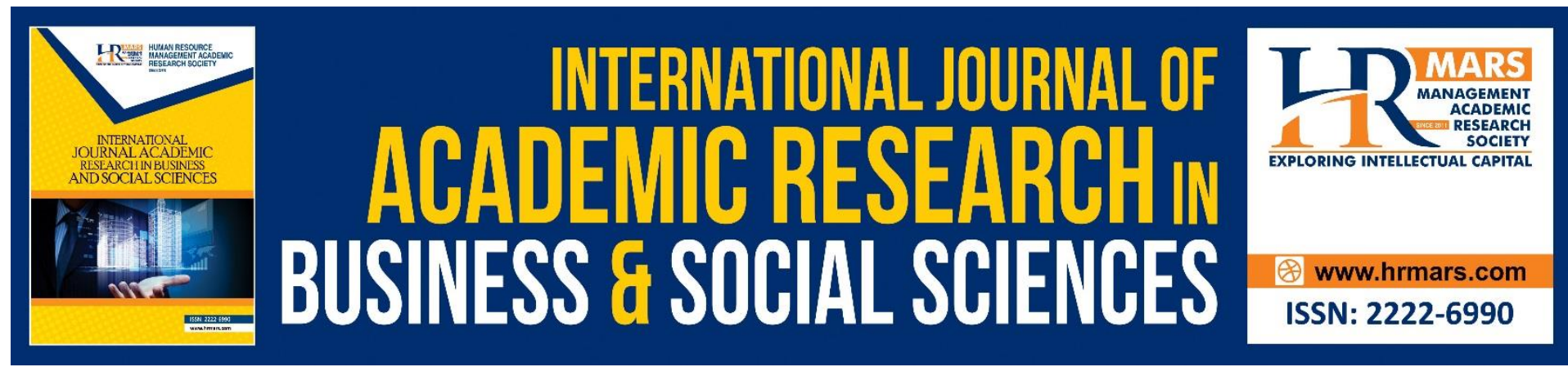

\title{
The Mutual Respect Method for Motivating Leaders and Followers
}

\author{
Noor Hidayah Samsudin, Fadzila Azni Ahmad \\ Centre for Islamic Development Management Studies (ISDEV), Universiti Sains Malaysia, \\ 11800 Minden, Pulau Pinang
}

\begin{abstract}
Leaders and followers have a dynamic relationship that could inspire and motivate each other. In Islam, it is generally considered that a leader is responsible for leading and guiding the followers and the followers in turn have the responsibility to follow their leader as long as the leader's actions are based on Islamic sharia. This shows that both, leaders and followers, need one another to enhance their motivation to implement each other's responsibilities. One method for enhancing motivation is through respect. Hence, what type of respect should exist between a leader and the followers, specifically in Islam? Although a leader holds a high position, should followers respect their leader without any basis or without the leader showing mutual respect? Do followers have to feel they are respected by their leaders in order for them to be continuously motivated? Based on these emerging questions, this article has two objectives, namely, to identify the concept of respect in an Islamic leadership and analyse that concept based on the relationship between a leader and the followers according to Islam. This article is qualitative in nature and data were obtained using the document research method. Findings show that although leaders hold a high position, the leader should respect the followers to ensure that they are always motivated in carrying out their responsibilities. Moreover, followers cannot hope that they will be respected by their leaders because at the same time they too should respect their leaders. Therefore, according to this mutual respect method, the motivation level of leaders and followers will be at an appreciable level needed for carrying out their respective tasks.
\end{abstract}

Keywords: Mutual Respect Method, Work Motivation, Leaders, Followers, Leadership

\section{Introduction}

Generally, a leadership will at least involve two categories, namely the one who leads or the leader and the one who is led, or the follower. According to Islam, a leader is clearly responsible for leading the followers by practicing a leadership method that is consistent with Islamic sharia. One of the tasks involved in leading is to motivate followers to perform their tasks and one of the methods used for doing so is through respect. In realising that the respect method is important in motivation, this article took the approach of examining the respect method in greater detail. Discussions begin with the section on Leaders and Followers in Institutions, followed by the Mutual Respect Method in Work Motivation section and lastly, the section on Conclusions. 


\section{Leaders and Followers in Institutions}

Development of a country cannot be implemented efficiently if the function of humans as citizens, which involves the development process comprising elements, such as governing, administrating, managing, handling and monitoring, cannot be carried out effectively (Johar, 2010). All these functions can be carried out by the citizens comprising those who govern and those who are governed, those who administer and those who are administered, those who manage and those who are managed, those who handle and those who are handled as well as those who monitor and those who are monitored. All functions that should exist in a country's development process are found in the management of an institution. This is similar to an institution where there is one party that governs, administers, manages, handles and controls, which is the management acting as a leader, while there is an another party that is governed, administered, managed, handled and monitored, which is the employee acting as a follower. This is shown in Diagram 1 below.

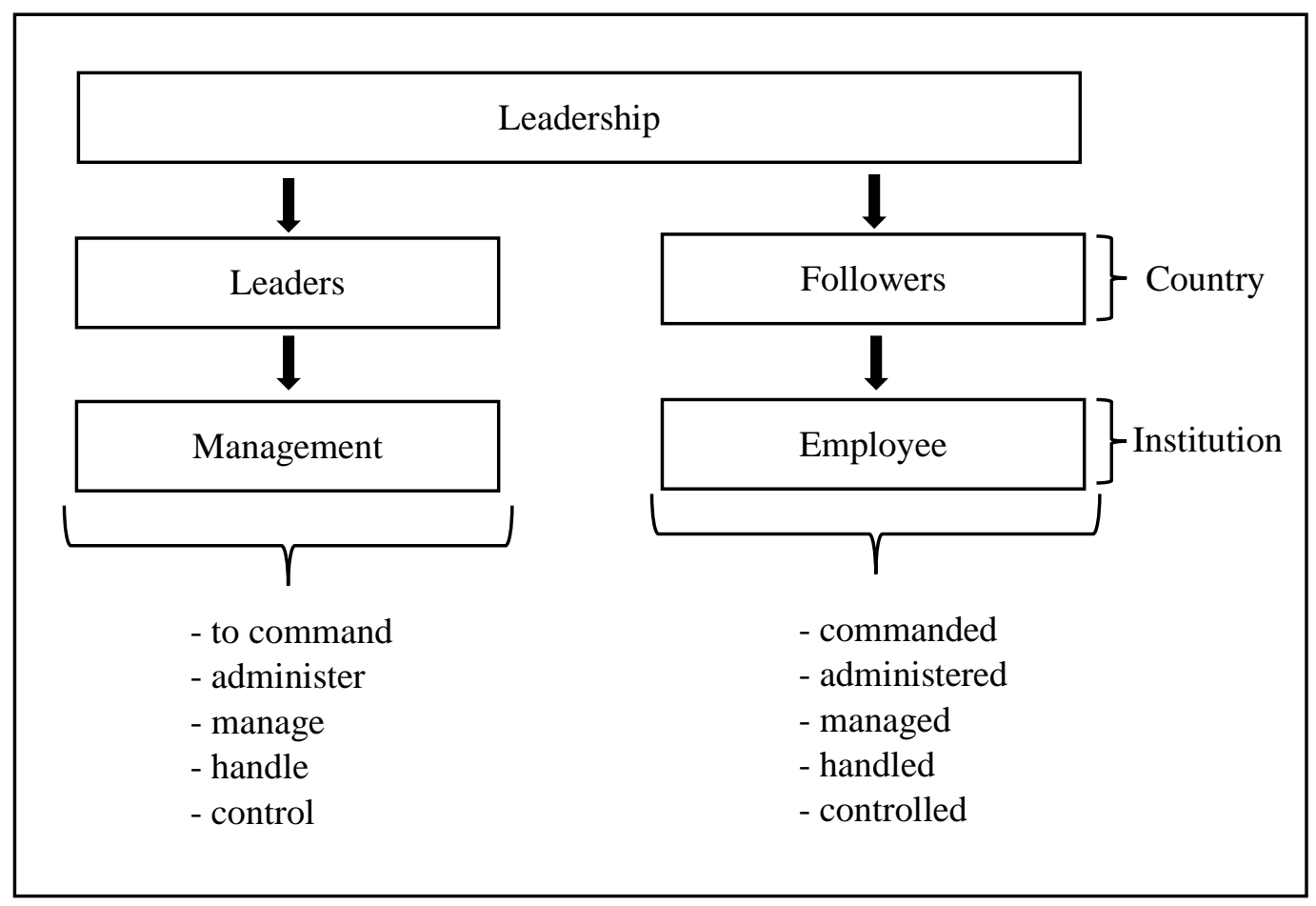

Diagram 1: Leadership Concept Between Leaders and Followers

Based on Diagram 1, it can be summarised that in the context of an institution, a leader refers to the management, which is responsible for leading, whereas followers refer to employees, who hold the trust and responsibility in an institution and are led by the management. An institution's management actually holds a big responsibility as a leader in the institution and one of the duties of a leader is to motivate employees (Mat, Case, Mohamaddan \& Yee, 2017). With this responsibility, the management can apply various methods that it feels confident will enhance employees' motivation.

One of the methods applied is the respect shown to employees. This is an important method for motivating employees since respect is one of the factors that influences the increase in employees' motivation (Abu, Zaidon \& Samsuri, 2006; Yusof, 2007; Porath, 2014; Zarei et al., 2016). However, the reality is that the rate of employees' desire to be respected is inconsistent with the rate of respect they receive, which is much lower (Rogers \& Ashforth, 
2017). Ehsan Zarei et al. (2016) said that the lack of motivation in employees has a negative effect not only on the employees but also on the institution's management. For example, absenteeism, not being enthusiastic in finishing the task and producing tasks that are of low quality. Lilly (2019) also stated that the most dangerous employees in an institution are those who are not respected.

Therefore, looking at the importance of the respect attitude and its effects, the management should be sensitive to this method in efforts to motivate their employees. Most studies on motivation have found that employees wish that the management will respect them so that their motivation will increase. This situation raises the question of whether it is only the management that should respect employees in order to motivate them. In fact, employees should also respect the management because the mutual respect attitude is the core trait of an Islamic management entity. Hence, it is evident that mutual respect in a management, which refers to the management and its employees respecting one another, is an important practice.

\section{The Mutual Respect Method in The Motivation to Work}

The mutual respect attitude is not something new in management, especially in Islamic management. This is because management has the opportunity to use the 'management motivates the employee' method to preach ( $\left.d a^{\prime} w a h\right)$, hence, Islam advocates that the management should respect employees although they are of different religion or ethnicity (Wani, Abdullah \& Lee, 2015). Islam actually emphasises that its subjects always respect every religion, ideology, culture and community that exists. Hence, if the management is truly Islamic in nature or a Muslim, then the management will not transgress what is advocated by Islam, but rather understand that Islam is propagated through respect given to others, for example, to employees.

Besides that, the mutual respect attitude amongst humans must be present in each Muslim who has confessed to have faith in Allah SWT because by practicing this attitude one is presumed to possess noble moral values (Department of Islamic Religion, Selangor, 2013). The attitude of respecting others is an important practice and should be upheld by every Muslim. However, if this attitude begins to erode it will affect inter-human relationships as well as Islam's image in the eyes of other religions. In the context of institutions, it is important that respecting others is practiced and assimilated in each individual so that a good social relationship between the management and employees is created (Yusof, 2007). A successfully cultivated mutual respect will create a comfort zone for the management as well as employees and this helps in communication and the efficient implementation of tasks.

Based on the analysis, it was found that the management should exhibit a sense of respect to its employees although in reality the management holds a higher position and is more influential. This is followed by various positive effects on employees' motivation if the management applies the respect method when managing employees. These effects are described in Diagram 2 below. 


\section{Diagram 2: Effect on Employees Who Are Respected by the Management}

Based on Diagram 2, there are various positive effects produced when the management respects its employees. The first effect is an employee's emotional stability, which is formed when the management begins to respect the employee. A management that is less

\begin{tabular}{|c|c|}
\hline & $\begin{array}{l}\text { 1) Has a positive effect on employees' emotions (Yusoff \& Mohamed, 2004; } \\
\text { Ramarana, Barsade \& Burack, 2008; Johar, 2010; Clarke, 2011) }\end{array}$ \\
\hline \multirow{5}{*}{ 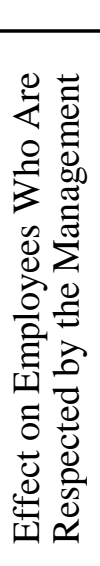 } & $\begin{array}{l}\text { 2) Increases employees' commitment and motivation to work (Porath, 2014; Arab \& } \\
\text { Atan, 2018) }\end{array}$ \\
\hline & $\begin{array}{l}\text { 3) Increases employees' level of satisfaction and happiness towards the management } \\
\text { and the work they are doing (Quaquebeke, Zenker \& Eckloff, 2009; Porath, 2014) }\end{array}$ \\
\hline & $\begin{array}{l}\text { 4) Employees always involve themselves in activities at the workplace (Ramarana, } \\
\text { Barsade \& Burack, 2008) }\end{array}$ \\
\hline & 5) Increase in employees' health and well-being (Porath, 2014) \\
\hline & 6) Employees become increasingly trusted and safe (Clarke, 2011; Porath, 2014) \\
\hline & $\begin{array}{l}\text { 7) Employees are more focused and give priority to their work (Porath, 2014; Carmeli, } \\
\text { Dutton \& Hardin, 2015; Yang, Ding \& Lo, 2016) }\end{array}$ \\
\hline & $\begin{array}{l}\text { 8) Employees feel they are more meaningful, important and loyal to the management } \\
\text { and institution (Porath, 2014; Perko, Kinnunen, Tolvanen \& Feldt, 2016) }\end{array}$ \\
\hline
\end{tabular}

knowledgeable about managing employees' motivation, in addition to the management itself experiencing work motivation and personality problems, will affect the management's emotions as well as that of its employees (Yusoff \& Mohamed, 2004; Ramarana, Barsade \& Burack, 2008; Johar, 2010; Clarke, 2011). Therefore, the management should take the initiative to improve itself in order to be more motivated and possess a better personality so that there is a positive impact on employees' emotions, which subsequently enhances their motivation to work. Employees in a better emotional state and with a higher level of motivation are more inclined to champion the objectives of the institution through an efficient attitude when implementing their tasks.

As for the second effect, when the management respects its employees, the employees will be more committed and motivated to carry out their tasks (Porath, 2014; Arab \& Atan, 2018). Findings also show that there is no managerial behaviour that has a greater effect on employees' motivation to work as the show of respect (Porath, 2014). To be treated with respect by the management is the most effective factor that motivates employees compared to appreciation, recognition or even the opportunity to participate in skills-related activities. Arab and Atan (2018) stated that when management respects and treats employees well, employees will feel that they have to return the good deed by increasing their work commitment. 
The third effect when employees are respected by the management is an increase in employees' level of satisfaction and happiness towards their management and the work they are performing (Quaquebeke, Zenker \& Eckloff, 2009; Porath, 2014). Besides that, Porath (2014) also found that employees who are respected by the management experience $89 \%$ increase in satisfaction and happiness in work situations.

The fourth effect shows that employees who are respected by the management have a greater tendency and frequently to involve themselves in the institution's activities (Lakshmi Ramarana, Barsade \& Burack, 2008). The respect shown by the management motivates the employees to contribute their energy towards the institution's activities, either activities organised by the management or external activities.

The fifth effect is the increase in health and well-being of employees whereby the respect shown by the management to its employees increases employees' health and well-being by 56\% (Porath, 2014).

The sixth effect shows that employees who are respected are more trustworthy (Clarke, 2011; Porath, 2014). Porath (2014) added that employees were 1.72 times more trustworthy and better at safeguarding the privacy and information about the institution if they are respected by the management (Porath, 2014).

The seventh effect, as shown in Diagram 2, indicates that employees who are respected by the management are more focused and lend priority to their tasks (Porath, 2014; Carmeli, Dutton \& Hardin, 2015; Yang, Ding \& Lo, 2016). Porath (2014) stated that employees feel 92\% more focused and lend priority to their tasks if the management respects them.

The eighth and final effect is that employees feel that they are more meaningful, more important and more loyal to the management and institution (Porath, 2014; Perko, Kinnunen, Tolvanen \& Feldt, 2016). Porath (2014) found that if respected by the management, employees feel 1.26 times more meaningful and important to the institution and 1.1 times more loyal towards the management and institution.

Based on discussions about the positive effects that emerge when the management motivates employees through the respect method, it is evident that the true influence of respect is to manage employees' motivation. The respect attitude's influence should exist in a management and its employees because if this attitude is absent, there will be negative repercussions. Effects that could emerge if the management does not respect employees are the constant heated atmosphere as well as rude and aggressive attacks on employees, which will make employees disappointed, anxious, fearful, pressured, angry, hateful and revengeful when facing the management and eventually become demotivated to work (Johar, 2004). These effects on employees will encourage them to be involved in various problems related to the motivation to work, behaviour, hypocritical attitude towards work, loss of focus, less productive, non-involvement in activities and tasks given, frequently experiencing health issues, and eventually leading to an increase in resignations (Ramarana, Barsade \& Burack, 2008; Porath, 2014). 
Therefore, it is clear that the absence of the respect attitude not only effects employees but also the management. When both parties do not have any self-respect as well as gain respect from others, their emotions are effected, which not only effects their work but also the quality of work, communication, level of satisfaction as well as the institution's performance (Zakaria \& Yahaya, 2006). Both, employees and the management, should practice mutual respect and it is inappropriate for the latter to wish the former to offer respect without the latter also offering some form of respect. Most employees in an institution react based on their experiences with their management (Lily, 2019). Thus, if the management gives respect, then the employees will reciprocate.

Islam has long emphasised the mutual respect concept (Elamin \& Tlaiss, 2015). Mutual respect is presumed to be a reactive relationship, for example, when $A$ respects $B, B$ will usually react with a feeling of respect to $A$, either in a similar fashion or in a greater show of respect (Wani, Abdullah \& Lee, 2015). This concept is mentioned in the al-Qur'an, as in Surah al-Nisa verse 86, meaning: -

"When a (courteous) greeting is offered you, meet it with a greeting still more courteous, or (at least) of equal courtesy. Allah takes careful account of all things."

Surah al-Nisa, 4: 86

In this verse, Allah SWT exhorted that when someone is respected and receives salutations, that person must return the respect and salutation in a much better way or at least similar to the salutation and respect received (Muhammad, 2016). It can be concluded that this verse shows that Allah SWT had called on Muslims to show mutual respect and return the respect to others. This Islamic concept should be considered by the management and employees of an institution. This means that in Islam itself the respect method should not be one-way whereby only one party shows respect and only one party is respected. It actually works twoways where there should be mutual respect between both parties. The mutual respect attitude in an institution can actually motivate and induce positive emotions in both, the management and its employees, which will surely affect the institution's development (Yusoff \& Mohamed, 2004).

Discussions have shown that Islam strongly encourages all Muslims, including those in institutions, to practice the mutual respect attitude, not only those who hold senior positions should be respected but all members of the institution. Most institutions have formally outlined their code of ethics, whereby the management and employees should be ethical when dealing with one another. One example of being ethical is to respect each other. Besides the mutual respect shown by the management and its employees, other elements that should be respected are freedom, dignity and personal matters (Adam \& Kassim, 2008).

Among the institutions that have clearly mentioned the need to have a mutual respect attitude in its code of ethics are the Public Services Department (JPA), Sime Darby Berhad and Tenaga Nasional Berhad. JPA had introduced the Excellent Work Culture (BKC), whereby in order to enliven this culture JPA had formed the JPA Code of Ethics (al-Qudsy, 2008). This code of ethics contains five codes and its ensuing features that need to be adhered to by all 
members of the institution, which refers to its top management and other employees. The five code of ethics are professionalism, teamwork, excellence and superiority, prudence and credibility as well as continuous learning. It was found that the second code, which is teamwork, considers the practice of mutual respect as one of the features that should exist for an employee to be motivated and achieve an excellent working culture. When examined further, respect is found in the code of ethics related to teamwork, which means that the management and employees make up the team in their institution and the respect factor is the basis for the existing relationship.

As for Sime Darby, the guideline for its Code of Ethics, or also known as COBC (Code of Business Conduct), has further explained the standard of work ethics that should be assimilated by all levels of employees, including the management and other employees (Sime Darby Berhad, 2011). One of the ethical values that should be assimilated by the management and employees is the mutual respect attitude. In this code of ethics, there are several evaluation questions that the management must answer and one of the questions is whether the management respects its employees. This shows the dire need for the management to respect its employees.

The third institution, Tenaga Nasional Berhad (TNB), has also issued its Code of Ethics to contain behavioural problems that could occur among all its employees, right from the top management until the lowest ranked employee (Tenaga Nasional Berhad, 2018). The management and employees should adhere to the standards contained in the code of ethics and one of the codes is to respect the individuals in the institution. All of them should respect each other by recognising each other's roles, treat each other well, listen to ideas and opinions as well as recognise the contributions of everyone.

Other than in Malaysia, institutions in Japan also prioritise the mutual respect attitude in order to enhance the motivation of individuals in their institutions. This type of attitude is nothing new to Japanese institutions because the Japanese have encultured the mutual respect attitude in their everyday lives. However, it is not only in Japan that this culture is emphasised but if the Japanese were to work in another country this culture will still be practiced. For example, it was found that Malaysian institutions that are managed by Japanese managers do emphasise the mutual respect attitude in these institutions (Suhada Saad \& Kartini Aboo Talib@Khalid, 2015). The mutual respect attitude involves all strata of society, for example the elderly, parents, top management and work mates. This practice has long been advocated by Islam, for example, Islam has outlined that individuals that should be respected are parents, fellow humans, those older than us, neighbours, guests, teachers as well as leaders (Department of Is/amic Religion Selangor, 2013). These individuals who should be respected are not limited to Muslims only but to everyone. One study involving 265 respondents comprising top management and employees from the automotive industry in Malaysia found that all of them agreed that mutual respect between them should exist at the work place although they come from various cultures, ethnic backgrounds and religions (Abdullah, Ismail \& Noor, 2016; Adawiyah \& Pramuka, 2017).

Mutual respect actually determines the future of an institution. This is because the method used by the management regarding behaviour and respecting employees during work will determine how employees behave during work and this determines whether the institution 
can progress further (Clarke, 2011; Walker, 2014). Employees' show of respect towards their management is influenced by various factors, among them are moral support from the management, cooperation as well as the management's attitude of showing concern and sympathy towards employees. Hence, if these elements are not present and exhibited by the management, then it will be difficult for employees to respect them.

In relation to this, an online survey involving 125 respondents intended to determine the level of respect these respondents received during their work (Porath, 2014). Findings show that $60 \%$ of respondents stated that they had too much work for them to behave well and respect their management. This is not an appropriate excuse since good behaviour and respect for the top management does not need extra hours or separate hours from the normal working hours. This is something that can be done during working hours or highlighted by communicating with the management and when personally meeting the management. Besides that, $25 \%$ of employees alleged that they did not have a role model on learning how to respect. Hence, they only behaved how their management behaved towards them. The excuse of not having a role model or a guide for employees to learn about respect should not prevail in the institution. This is because the management, which is the top management and head of the employees, should play an exemplary role that employees can follow when working in the institution and not as a source that causes employees to become increasingly demotivated and frequently placed in a pressured situation (Johar, 2010).

Islam's image is portrayed as a religion that upholds the mutual respect attitude successfully portrayed by the Prophet SAW. The Prophet SAW has been a good example to HIS subjects on how to respect others (Wani, Raihanah \& Lee, 2015). As an idol for all Muslims, the Prophet SAW should be a guide for the management of the respect method used by the Prophet SAW that has made HIM an idol. Among the methods advocated by Islam that show respect for others are to provide friendly and polite treatment to others, mutual cooperation, appreciating one another, appreciating the good deeds and services obtained as well as practicing good and harmonious communication (Zakaria \& Yahaya, 2006; Department of Islamic Religion, Selangor, 2013). Practicing these methods, especially good communication skills, can create a feeling of mutual respect between the management and its employees, which will increase employees' motivation to work and achieve a high level of work satisfaction (Rani, Nur 'Abdullah, Harun, 2017).

\section{Conclusion}

Mutual respect has been long advocated by Islam, not only amongst Muslims but also amongst people of other religions too. This should be heeded by all management authorities in various institutions, especially the management in Islamic institutions. Besides the management, employees should also understand that they cannot demand respect from the management in order to enhance their motivation but instead they too have to respect the management.

Advocating the concept of mutual respect, which actually exists in Islam, should be applied in institutions so that the motivation to work by both the management and employees is enhanced. Importance of the concept of mutual motivation has been proven through studies as well as views of scholars, which mentions about the positive effects of practicing the mutual respect method. These positive effects clearly have an effect on emotions, 
commitment, work involvement, work satisfaction, health, happiness as well as the motivation to work by both, management and employees. These positive effects not only impact the employees and management but more so the development and image of the Islamic institution.

Therefore, it is clear that the mutual respect method is actually an important practice that should be practiced by all institutions, regardless whether it is a conventional or Islamic institution. Hence, for Islamic institutions, both the management and its employees, should practice this method since Islam itself, through the al-Qur'an and the Prophet SAW, has indicated the significance of practicing mutual respect in Islam

\section{Acknowledgement}

The authors would like to acknowledge for the financial supports given by Bridging Grant (304/CISDEV/6316257) from Universiti Sains Malaysia (USM), Malaysia.

\section{References}

Yusof, A. A. (2007). Keinsanan dalam pengurusan. Utusan Publications and Distributors Sdn Bhd.

Elamin, A. M., \& Tlaiss, H. A. (2015). Exploring the relationship between organizational citizenship behavior and organizational justice in the Islamic Saudi Arabian context. Employee Relations, 37(1), 2-29. https://doi.org/10.1108/ER-03-2014-0033

Abdullah, A., Ismail, M. M., \& Noor, M. M. (2016). Etnisiti di tempat kerja: Menghormati perbezaan, meraikan kepelbagaian. Research Journal of Social Science, 9(3), 52-58.

Carmeli, A., Dutton, J. E., \& Hardin, A. E. (2015). Respect as an engine for new ideas: Linking respectful engagement, relational information processing and creativity among employees and teams. Human Relations, 68(6), 1021-1047. https://doi.org/10.1177/0018726714550256

Clarke, N. (2011). An integrated conceptual model of respect in leadership. The Leadership Quaterly, 22, 316-327. https://doi.org/10.1016/j.leaqua.2011.02.007

Zarei, E., Najafi, M., Rajaee, R., \& Shamseddini, A. (2016). Determinants of job motivation among frontline employees at hospitasls in Tehran. Electronic Physician, 8(4), 22942254. https://doi.org/10.19082/2249

Arab, H. R., \& Atan, T. (2018). Organizational justice and work outcomes in the Kurdistan region of Iraq. Management Decision, 56(4), 808-827. https://doi.org/10.1108/MD-042017-0405

Wani, H., Abdullah, R., \& Lee, W. C. (2015). An Islamic perspective in managing religious diversity. Religions, 6, 642-656. https://doi.org/10.3390/rel6020642

Ramarana, L., Barsade, S. G., \& Burack, O. R. (2008). The influence of organizational respect on emotional exhaustion in the human services. The Journal of Positive Psychology, 3(1), 4-18. https://doi.org/10.1080/17439760701750980

Lilly, J. (2019). The most dangerous employees in the workplace: Those who feel excluded and disrespected. Development and Learning in Organizations. https://doi.org/10.1108/DLO-08-2019-0183

Yusoff , M. S. M., \& Mohamed, N. S. (2004). Peningkatan prestasi di tempat kerja melalui aplikasi kecerdasan emosi. Jurnal Pengurusan Awam, 3(1), 1-20.

Rani, N. J. I., Abdullah, N. A. N. D., \& Harun, N. (2017). Keberkesanan komunikasi dan kepuasan kerja dalam kalangan pensyarah. Kertas kerja dibentangkan di The 4th International 
Conference on Management and Muamalah 2017 (ICOMM 2017) pada 7-8 November 2017 di Palm Garden Hotel, Putrajaya.

Perko, K., Kinnunen, U., Tolvanen, A., \& Feldt, T. (2016). Back to basics: The relative importance of transformational and fair leadership for employee work engagement and exhaustion. Scandinavian Journal of Work and Organizational Psychology, 1(1), 1-13. https://doi.org/10.16993/sjwop.8

Porath, C. (2014). Half of employee don't feel respected by their bosses. Harvard Business Review. https://hbr.org/2014/11/half-of-employees-dont-feel-respected-by-theirbosses

Quaquebeke, N. V., Zenker, S., \& Eckloff, T. (2009). Find out how much it means to me! The importance of interpersonal respect in work values compared to perceived organizational practices. Journal of Business Ethics, 89, 423-431. https://doi.org/10.1007/s10551-008-0008-6

Rogers, K. M., \& Ashforth, B. E. (2017). Respect in organizations: Feeling valued as "we" and "me". Journal of Management, 43(5), 1578-1608. https://doi.org/10.1177/0149206314557159

Abu, S., Zaidon, S., \& Samsuri, S. S. (2006). Panduan untuk pengusaha tadika. PTS Profesional \& Publishing Sdn. Bhd.

Mat, S., Case, K., Mohamaddan, S. \& Yee, M. G. (2017). A study of motivation and learning in Malaysian manufacturing industry. Production \& Manufacturing Research, 5(1), 284305. https://doi.org/10.1080/21693277.2017.1374892

Zakaria, S. A. S., \& Yahaya, A. S. (2006). Tinjauan tentang reaksi emosi di tempat kerja: Satu aspek pengurusan sumber manusia dalam organisasi. Jurnal Teknologi, 44(E), 1-11.

Al-Qudsy, S. H. (2008). Budaya kerja cemerlang menurut perspektif Islam: Amalan Perkhidmatan Awam Malaysia. Jurnal Pengajian Melayu, 19, 187-207.

Johar, S. S. (2010). Dimensi personaliti psikotisisme di kalangan ketua dan impaknya terhadap estim kendiri pekerja di tempat kerja. Kertas kerja dibentangkan di International Conference on the Roles of the Humanities and Social Sciences in Engineering 2010 pada 12-14 November 2010 di Universiti Malaysia Perlis, Perlis. https://core.ac.uk/download/pdf/12007095.pdf

Embong, A. H., Khairuldin, W. M. K. F. W., Yasin, M. F. M., Hassan, A., \& Ibrahim, M. S. (2021, March). Between Reformist and Interpretation: Notes on Hamka's Methodological Strategies as Reformist Mufassir. In First International Conference on Science, Technology, Engineering and Industrial Revolution (ICSTEIR 2020) (pp. 415-422). Atlantis Press.

Majid, S. F., Khairuldin, W., \& Ajmain, M. T. (2019). Fiqh Boycott On LGBT Community: A Review. Perdana: International Journal of Academic Research, 6(2), 35-49.

Anas, W. N. I. W. N., Daud, N., Khairul, W. M., \& Khairuldin, F. W. (2017). The Stance of Alimony or Maintenance for Working Wives within Working Period: An Analysis from the Qualified Jurists (Muftis). International Journal of Academic Research in Business and Social Sciences, 7(4), 2222-6990.

Hassan, S. A., \& Khairuldin, W. (2020). Research Design Based on Fatwa Making Process: An Exploratory Study. International Journal of Higher Education 9 (6), 241-246

Saad, S., \& Khalid, K. A. (2015). Implementasi budaya kerja Jepun dalam organisasi di Malaysia. Malaysia Journal of Society and Space, 11(6), 1-10. 
Walker, A. N. (2014). The examination of organizational respect in relation to organizational culture (Tesis sarjana muda tidak diterbitkan). University of New Hampshire: United States of America.

Adawiyah, W. R., \& Pramuka, B. A. (2017). Scaling the notion of Islamic spirituality in the workplace. Journal of Management Development, 36(7), 877-898. https://doi.org/10.1108/JMD-11-2014-0153

Yang, C., Ding, C. G., \& Lo, K. W. (2016). Ethical leadership and multidimensional organizational citizenship behaviors: The mediating effects of self-efficacy, respect, and leader-member exchange. Group \& Organization Management, 41(3), 343-374. https://doi.org/10.1177/1059601115594973

Adam, Z., \& Kassim, F. (2008). Kemahiran kerja berpasukan: Etika dalam pekerjaan dari perspektif Islam. Kertas kerja dibentangkan di Kemahiran Kebangsaan Kemahiran Insaniah dan Kesejahteraan Sosial pada 18-19 Ogos 2008 di Hotel Mahkota, Melaka. http://irep.iium.edu.my/id/eprint/7989 